Agro-Science Journal of Tropical Agriculture, Food, Environment and Extension Volume 16 Number 3 (September 2017) pp. $1-8$

ISSN 1119-7455

\title{
COMPARATIVE EFFECTS OF THREE LEVELS OF INSECT INFESTATION ON SELECTED PROPERTIES OF FIVE NIGERIAN COWPEA (Vigna unguiculasta (L.) WALP) VARIETIES
}

\author{
${ }^{1}$ Akah, N.P. and ${ }^{2}$ Onyeka, E.U. \\ ${ }^{1}$ Department of Food Science and Technology, University of Nigeria Nsukka. \\ ${ }^{2}$ Department of Food Science and Technology, Federal University of Technology, Owerri, \\ Imo State, Nigeria. \\ email: nkechi4allreaders@yahoo.com; ulomaonyeka@yahoo.com
}

\begin{abstract}
Effect of three insect infestation levels (25\%, 50\% and 75\%) on selected properties of five Nigerian cowpea varieties (Ife brown, Iron beans, Isiocha, Patasco, and Sokoto white) were compared and studied. Infestation levels of each variety were obtained by counting and combining infested and uninfested seeds. Samples were analyzed for protein, total dietary fiber (TDF), blue value index (BVI), swelling index (SI), foaming capacity $(F C)$ and foam stability (FS). Infestation at all levels significantly $(p<0.05)$ reduced mean TDF $(12 \%-21 \%)$, SI (3\%-13\%) and FS $(22 \%-37 \%)$ of the cowpeas. Infestation also significantly $(p<0.05)$ reduced protein $(21 \%-24 \%)$ and $F C(21 \%-41 \%)$ of the cowpeas while it significantly $(p<0.05)$ increased BVI $(49-80 \%)$. No significant difference $(p>0.05)$ was observed between mean values of control and $25 \%$ infested samples for BVI and FC. No significant difference $(p>0.05)$ was observed among mean values of $25 \%, 50 \%$ and $75 \%$ infested cowpeas for FS and between mean values of $25 \%$ and $50 \%$ infested cowpeas for protein. Infestation caused higher reduction in protein and FS of Iron beans and higher increase in BVI and decrease in FC of Isiocha and Sokoto white. Patasco was least affected by insect infestation in protein content, level of starch damage and foaming capacity; Iron was least affected in TDF and SI while Ife brown was the least affected in foaming stability. Un-infested samples were better in all properties evaluated and these varied among the varieties. Un-infested Sokoto possessed better foam properties, with $2.0 \mathrm{~g} / \mathrm{g}$ foam stability.
\end{abstract}

Key words: Cowpea varieties, infestation levels, blue value index, protein, Nigeria.

\section{INTRODUCTION}

Cowpea has been one of the most ancient and important food legumes in Africa, Asia and the Mediterranean countries for more than 3500 years (Gayan et al., 2006). It is the most important grain legume crop in Sub-Saharan Africa according to CGIAR (2017) and a major staple and source of inexpensive protein and other vital dietary components such as dietary fiber, calories, minerals, B-vitamins and essential fatty acids, especially among West Africans (National Research Council, 2006; Abudulai et al., 2016; CGIAR, 2017; Kyei-Boahen et al., 2017; Singh and Mukhi, 2017). Annually, about 12-15 million hectares of land is cultivated with cowpea worldwide with the Sub Saharan Africa accounting for the bulk of the total area of production (about 12 million hectares) and Nigeria responsible for about $1 / 3^{\text {rd }}$ (4-5 million hectares) of total world production area. Nigeria is the largest producer and consumer of cowpea globally with an estimated annual production of 2-3 million tons or about $60 \%$ of the world's total annual production of about 5 million tons (Ajetomobi and Abiodun, 2010; African Agricultural Technology Foundation, 2012; Oyewale and Bamaiyi, 2013; Kamai et al., 2014; Kamara et al., 2016; Ahmad and Kiresur, 2016; CGIAR, 2017; FAO, 2016). In Nigeria, cowpea is mainly consumed in the dried seed form as porridge or in combination with foods such as cereals e.g. rice, or processed into paste which is used in making the popular relished 'akara' and 'moin-moin' (Oboh and Agu, 2010; Odejayi et al., 2014). It is also used as composite flour in the production of infant foods and baked and fried products such as bread, cake and chin-chin where they improve especially the protein quality of the products (Uzogara and Ofuya, 1992; Akubor, 2004; Oladunmoye et al., 2010; Vilakati et al., 2015).Unfortunately, cowpea is prone to heavy

Please cite as: Akah, N.P. and Onyeka, E.U. (2017) Comparative effects of three levels of insect infestation on selected properties of five Nigerian cowpea (vigna unguiculasta (1.) walp) varieties. Agro-Science, 16 (3), 1-8 DOI: https://dx.doi.org/10.4314/as.v16i3.1 
field and post harvest infestation damage and this constitutes one of the major constraints to its optimal utilization as food as well as limits its contribution to food security (Kungu et al., 2003). Cowpea is attacked in the field where yield reductions of 20 to over $90 \%$ by the field insect pests such as Megalurothrips sjostedti, Aphis craccivora, Helicoverpa armigera and Maruca vitrata has been reported in Cameroun and Nigeria and in some other producing countries (Carlos, 2004; Ngakou et al., 2010; Muchero et al., 2010; Margam et al., 2011; Abudulai et al., 2016; Sangoyomi and Olufunmilola, 2016; Alale et al., 2017; Kattula et al., 2017). Cowpea is further severely damaged in the store by the foremost cowpea storage pest, the cowpea weevil Callosobruchus maculatus Fab. Mylabridae, which bore hole into the seeds resulting in loss of food grain and quality.

The losses incurred by this weevil to cowpea in storage is reported to reach $100 \%$ sometimes, if left unattended, compelling many farmers in Africa, Asia and Southern America to dispose of their crops soon after harvest thus reducing an important protein and income source for their families (Sanon et al., 2010; Ajayi et al., 2015; Oyeniyi et al., 2015). Significant losses in weight, viability, protein content, essential amino acids, total fat, mineral matter, vitamins, soluble sugars, starch digestibility, emulsification, foam and viscosity properties and increase in free fatty acids and peroxides of insect-infested grains were reported (Ojimelukwe et al. 1999; Sallam, 2008; Odejayi, et al., 2014). Jood et al. (1993) reported deleterious effects on protein quality (such as biological value, net protein utilization and nitrogen absorption) and growth performance of study rats fed insect infested sorghum grains. The activity of insect pests in stored grains was also found to leave behind sloughs, frass and other secretions and to raise the products temperature and humidity which all predispose the grains to bacterial and fungi contamination especially aflatoxin poisoning, suggesting the potential danger infested cowpea can pose to the consumer in addition to losses in nutrients, functional properties and unpleasant sensory qualities (Carlos, 2004; Sallam, 2008; Odejayi, et al., 2014; Odejayi and Aina, 2016).

It is still common place to find both moderately to severely infested cowpeas in Nigerian markets as consumers tend to ignore the consequences of infestation on the nutrient quality if the physical appearance, organoleptic and/or functional properties have not deteriorated appreciably (Ojimelukwe et al., 1999). Many researchers had earlier worked on cowpea and generally compared infested cowpeas with un-infested cowpeas. There is paucity of information on the effect of infestation on the qualities (such as total dietary fiber (TDF) and blue value index (BVI)) of cowpeas at different degrees of infestation. This is necessary to determine the acceptability and usefulness of the infested cowpeas at different levels of infestation. This study was therefore carried out to evaluate the effect of different infestation levels on nutritional and functional properties of five Nigerian cowpea varieties.

\section{MATERIALS AND METHODS}

Seeds of Ife-brown, Iron, Isiocha, Patasco and Sokoto white cowpea varieties (Figures 1-5) used for this study were purchased from Eke Ukwu Market in Owerri, Eastern Nigeria.

\section{Preparation of samples}

Seeds of each variety were sorted into infested and un-infested seeds. Un-infested and infested seeds of each variety were then combined by counting on 1000 seeds basis to obtain samples of $0 \%, 25 \%, 50 \%$ and $75 \%$ levels of infestation. Table 1 shows how the samples were generated. Each sample was de-hulled, winnowed and milled into flour using a hammer mill. The samples were packaged in low density polyethylene wraps and stored in an air-tight container until used for analysis.

\section{Crude protein determination}

The Kjeldahl method described by A.O.A.C (2010) was used. Each sample $(0.1 \mathrm{~g})$ was mixed with $20 \mathrm{ml}$ of concentrated $\mathrm{H}_{2} \mathrm{SO}_{4}$ in a Kjeldahl flask. A small amount of a mixture of copper sulphate and anhydrous sodium sulphate catalyst was added to the flask and the mixture heated inside a fume cupboard. The digest was transferred into a $100 \mathrm{ml}$ volume flask and diluted to mark with distilled water. An aliquot of the digest $(20 \mathrm{ml})$ was mixed with equal volume of $45 \% \mathrm{NaOH}$ solution in a semi-micro Kjeldhal distillation apparatus. The mixture was distilled and the distillate collected into $10 \mathrm{ml}$ of $4 \%$ boric acid solution containing 3 drops of mixed indicator, methyl red and bromocressol green. A total of $30 \mathrm{ml}$ distillate was collected and titrated against $0.01 \mathrm{~N} \quad \mathrm{H}_{2} \mathrm{SO}_{4}$ solution. The percentage nitrogen content was calculated and multiplied with 6.25 to obtain the crude protein content.

$$
\mathrm{N} \%=\frac{(100 \times \mathrm{n} \times 14 \times \mathrm{VF}) \mathrm{T}}{100 \times \mathrm{Va}}
$$

Where $\mathrm{N} \%=$ percent nitrogen content; $\mathrm{n}=$ normality of acid used; $\mathrm{VF}=$ total volume of the digest $=100 \mathrm{ml} ; \mathrm{T}=$ titre value; $\mathrm{Va}=$ aliquot volume distilled. 


\section{Total dietary fibre determination}

Total dietary fiber (TDF) was determined by the method of AOAC (2010). One gram $(1 \mathrm{~g})$ weight of each sample was mixed with $10 \mathrm{ml}$ of distilled water in a beaker and gelatinized in a water bath (whilst stirring continuously) followed by digestion or incubation with termamyl enzyme ( $\left.\mathrm{pH} 6,100^{\circ} \mathrm{C}, 30 \mathrm{~min}\right)$. At the end of termamyl incubation, the $\mathrm{pH}$ of the sample was adjusted to 7.5 with $1.25 \% \mathrm{NaOH}$. The temperature of the sample was adjusted to $60^{\circ} \mathrm{C}$, protease was added and sample incubated at this temperature for $30 \mathrm{~min}$. The sample was subsequently incubated at $60^{\circ} \mathrm{C}$ with amyloglucosidase for $30 \mathrm{~min}$ after adjustment to $\mathrm{pH} 4.5$ with acetic acid. The total dietary fiber was precipitated with four volumes of ethanol, followed by filtration and washing of the residue with ethanol and acetone, and drying in an oven at $100^{\circ} \mathrm{C}$. The total dietary fiber was calculated as

$\mathrm{TDF}=$ weight of residue after drying $\times 100$ weight of sample

\section{Swelling index determination}

Swelling index was determined by the method of Ukpabi and Ndimele (1990). Three gram (3 g) portions of each flour sample were transferred into clean, dry graduated $(50 \mathrm{ml})$ cylinders. The flour samples were gently leveled and the volumes noted. Distilled water (30 $\mathrm{ml})$ was added to each sample; the cylinder was swirled and allowed to stand for 60 minutes. The swelling power of each flour sample was calculated as

Swelling Index $=$ volume of sample after swelling original volume of sample

\section{Determination of foaming capacity and foam stability}

Foaming capacity and foam stability were determined as described by Lawhen et al. (1972). One gram (1g) weight of each flour sample was mixed with $10 \mathrm{ml}$ distilled water using a magnetic stirrer (PHYWE) at 10 Ruhrer speed at room temperature for $5 \mathrm{~min}$. The whipped mixture was transferred into $25 \mathrm{ml}$ graduated cylinder and the foam volume read after $30 \mathrm{sec}$. The volume of foam at 30 sec was regarded as foam capacity and the volume after $30 \mathrm{~min}$ standing as foam stability.

\section{Blue value index determination}

BVI was determined by the method of Kawabata et al. (1984). One gram (1g) weight of each flour sample was dispersed in $10 \mathrm{ml}$ distilled water. The dispersion was stirred occasionally for $30 \mathrm{~min}$, and then filtered through What-man No. 42 filter paper. Two ml of the filtrate was transferred into a conical flask and 4 drops of phenolphthalein was added and titrated with $0.1 \mathrm{~N}$ iodine solution. The titre value was recorded and BVI calculated as

BVI $(\mathrm{ppm})=\left\{\left(\mathrm{V}_{\mathrm{D}} / \mathrm{V}_{\mathrm{A}}\right)\left(\mathrm{X} / \mathrm{M}_{\mathrm{f}}\right)(\mathrm{N} / 1000)\right\} \times 10^{6}$ Where $\mathrm{V}_{\mathrm{D}}=$ total volume of dispersion; $\mathrm{V}_{\mathrm{A}}=$ volume of aliquot used in titration;

$\mathrm{X}=$ titre value; $\mathrm{M}_{\mathrm{f}}=$ weight of flour sample used; $\mathrm{N}=$ normality of iodine solution used

\section{Statistical analysis:}

Data obtained from the study were computed into means $\pm \mathrm{SD}$. Analysis of variance (ANOVA) was used to detect any significant difference due to insect infestation. Where significant differences exited, Fishers Least Significant Difference (F-LSD) was used to separate the means. Significant difference in sample means was accepted at $\mathrm{p}<0.05$.

\section{RESULTS AND DISCUSSION}

Protein content: Table 2 shows the protein content of the un-infested and infested cowpeas. The mean protein content of uninfested samples, $19.97 \%$ (varying between $15.31 \%$ in Isiocha and $22.75 \%$ in Ife br own and Iron) did not differ significantly $(\mathrm{P}>0.05)$ from the mean protein content of $75 \%$ infested cowpeas $(17.68 \%)$ but differed significantly $(\mathrm{P}<0.05)$ from the mean protein content of $25 \%(15.73 \%)$ and $50 \%(15.18 \%)$ infested cowpeas. The mean protein content of $25 \%$, $50 \%$ and $75 \%$ infested cowpeas was not significantly $(\mathrm{P}>0.05) \quad$ different. Insect infestation significantly $(\mathrm{P}<0.05)$ reduced mean protein content of the cowpeas by 21 $24 \%$ with $50 \%$ infestation causing the highest reduction of $24 \%$. Reduction in protein content due to infestation was highest in Iron (50\%) and least in patasco (5\%) (Table 2). The protein content of un-infested Ife brown (22.75\%), Iron (22.75\%) and Patasco (21.56\%) agreed with the range (22-25\%) recorded for un-infested cowpeas (Ihekoronye and Ngoddy, 1985). Depletion in protein content of infested cowpeas was similarly observed by Ojimelukwe et al. (1999). Ojimelukwe et al. (1999) reported a decrease of $19 \%$ and $28 \%$ in protein content of Kano white and Ife brown varieties, respectively which agreed with 21 $24 \%$ decrease in protein content observed in this study. Depletion in protein content of infested samples was attributed to utilization of the protein nutrient by the insects (Ojimelukwe et al., 1999). The increase in mean protein content of $75 \%$ infested cowpeas cannot be a true increase in protein content. Jood et al. (1993) noted that no matter the direction of change in the nitrogen content of infested grains, the true protein content of such grains 
Comparative Effects of Three Levels of Insect Infestation on Selected Cowpea Varieties

decrease and the real nutritional value of protein is not reflected in chemical analysis of infested cowpeas because of a number of factors like presence of insect excreta and body fragments among others. Biological evaluation of protein quality is most desirable in such situation according to Jood et al. (1993).
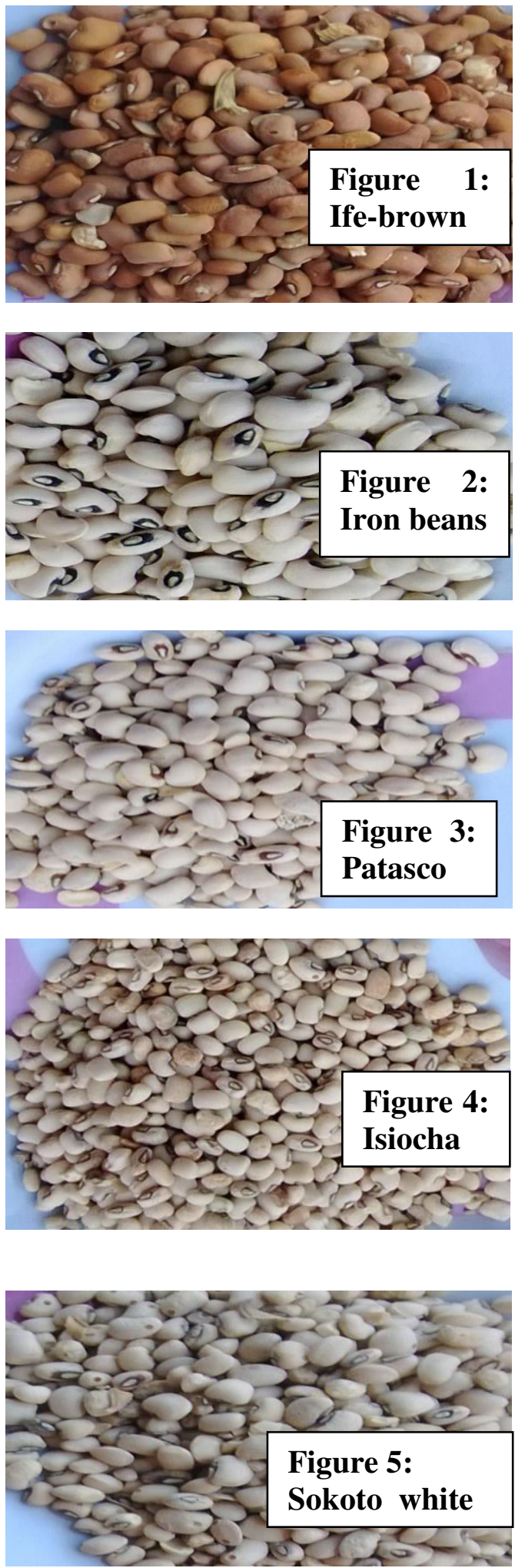

Figures 1-5: Nigerian Cowpea Varieties Total dietary fibre:
The total dietary fiber of the un-infested and infested cowpeas is presented in Table 2. The TDF of un-infested cowpeas varied from $34 \%$ in Patasco to $49 \%$ in Iron beans and Isiocha with a mean TDF value of $42.60 \%$ which was significantly different $(\mathrm{P}<0.05)$ from the mean TDF value $(33.6-37.6 \%)$ of the infested samples. Infestation at all levels significantly $(\mathrm{p}<0.05)$ reduced mean TDF of the cowpeas by $12-21 \%$ with $75 \%$ infestation causing the highest reduction. Highest reduction in TDF $(35 \%)$ occurred in Isiocha while the least reduction in TDF occurred in iron beans $(4 \%)$ at $75 \%$ infestation level. The TDF of the uninfested cowpeas (34-49\%) was in close agreement with the range of 20.9 to $46.9 \mathrm{~g} / 100$ $\mathrm{g}$ TDF reported for a number of legumes including soybean, peanut and cowpea among others by Mallillin et al. (2008). Decrease in TDF in the infested cowpea samples was attributed to feeding on the soluble portion of TDF by the insects. Lon (2005) reported that all animals use nearly all of the soluble fiber ingested. The high TDF recorded for the uninfested cowpeas makes them of considerable physiological and health benefits in terms of regulation of blood sugar, cholesterol lowering, and prevention against heart disease, diabetes and certain forms of cancer among other physiological benefits (Anderson et al., 2009).

\section{Blue value index (BVI):}

The BVI of the un-infested and infested cowpeas is presented in Table 2. The BVI of un-infested samples varied from $37.50 \mathrm{ppm}$ in Iron and Sokoto to $51.25 \mathrm{ppm}$ in Ife brown. Infestation significantly $(\mathrm{P}<0.05)$ increased mean BVI of the cowpeas from $20 \%$ at $25 \%$ infestation level to $80 \%$ at $75 \%$ infestation level, indicating significant $(\mathrm{P}<0.05)$ starch damage of the cowpeas by infestation. The mean BVI of control samples did not differ significantly $(\mathrm{P}>0.05)$ from that of $25 \%$ infested cowpeas (Table 2). However, at 25\% infestation level, BVI increased by $32 \%$ in Isiocha to $53 \%$ in iron beans but by only $2 \%$ in Ife brown and $18 \%$ in patascco. Significant starch damage at $25 \%$ level of infestation may therefore be said to have occurred in all the varieties except in Ife brown. Generally, infestation caused a higher increase in the BVI of Isiocha and Sokoto, causing over 100\% increase in their BVI, respectively. This may indicate more fragility of starch granules than the other varieties (Mbofung, 2006). BVI values for un-infested cowpea samples suggest thermal and mechanical damage of starch granules which according to Ezema (1989) occur during grinding or milling into flour. 
Blue value index is used to represent the degree of starch damage or fragility (Mbofung, 2006) and to correlate the amount of free starch from mechanically damaged cells (Lulai, 1983); the higher the starch damage or damage of starch granules, the higher the BVI. The high increase $(20-80 \%)$ in BVI of the infested cowpeas showed that infestation severely damaged their starch granules and consequently reduced their SI which according to Ezema (1989) depend partly on the extent of starch damage. The higher reduction in BVI recorded for Isiocha and Sokoto shows the extent infestation can limit their usefulness in making the relished akara for which they are most suitable and used for traditionally.

\section{Swelling index (SI)}

The swelling index of the un-infested and infested cowpeas is presented in Table 2. The SI of un-infested samples varied from $1.29 \mathrm{ml}$ in Patasco to $1.61 \mathrm{ml}$ in Ife brown with a mean SI value of $1.42 \mathrm{ml}$ which differed significantly $(\mathrm{P}<0.05)$ from the mean SI value for $25 \%$ $(1.38 \mathrm{ml}), 50 \%(1.31 \mathrm{ml})$ and $75 \%(1.23 \mathrm{ml})$ infested samples. Infestation at all levels significantly $(\mathrm{P}<0.05)$ reduced the mean SI of the cowpeas $(3-13 \%)$ and $75 \%$ infestation caused the highest reduction in SI. Infestation least affected the swelling index of iron beans, causing only $1-6 \%$ reduction in its SI while up to $14-16 \%$ reduction was recorded in the other varieties. Decrease in the swelling index of the infested cowpeas was attributed to reduction in protein, TDF and starch damage by infestation. Enwere (1985) reported that proteins in flour contributed to swelling to about 3.75 times its original volume while Ezema (1989) reported that the extent of swelling in the presence of water depends on extent of starch damage and carbohydrates such as pectins, hemicelluloses and celluloses. Swelling of starch granules result in increased viscosity as a result of gelatinization and this phenomenon according to Enwere (1985) is the basis for the production of cowpea products 'akara' and 'moin-moin' where the starch in cowpea flour swell when heated in excess of water above $60^{\circ} \mathrm{C}$ to about 6.13 times their original volume by initially absorbing water, gelatinizing and then swelling. Infested cowpea seeds would therefore not be suitable for making moin-moin and akara.

\section{Foaming capacity (FC) and foam stability (FS):}

About $13 \%$ to $41 \%$ reduction in $\mathrm{FC}$ was observed for the cowpeas with $75 \%$ infestation causing the highest decrease in FC. The FC of patasco was not apparently affected by infestation, $25 \%$ infestation did not affect Ifebrown while 25 and $50 \%$ infestation did not affect Iron.

Infestation reduced FC of Isiocha and Sokoto more than it did the other varieties. The FS of un-infested cowpeas varied between 1 and 2 $\mathrm{ml}$ (Table 2). Un-infested Sokoto had the highest FS $(2.0 \mathrm{ml})$ and was not affected by $25 \%$ infestation. Infestation did not affect FS of Ife brown but caused the highest reduction of $90 \%$ in that of Iron. Nevertheless, infestation decreased the mean FS of infested cowpeas by $22-37 \%$ (Table 2).

Reduction in foam properties of the infested cowpeas was similarly observed by Ojimelukwe et al. (1999). Kinsella (1979) reported that foam formation and stabilization is a surface-active function of proteins while Okaka and Potter (1979) observed a direct relationship between foaming properties and protein solubilities. Ojimelukwe et al. (1999) further noted that the rate of collapse, which is an index of foam stability, depends on the extent of protein denaturation and alterations in the protein molecules. The observed decrease in FC and FS of the infested cowpeas could therefore be attributed to decrease in protein especially in soluble protein fractions as well as to protein denaturation by infestation. Foaming capacity and foam stability properties are useful in preparing 'akara' as the foam formed when cowpea paste is whipped holds the incorporated air and enables the bean balls to retain their unique spongy and firm shape after frying. Uninfested Sokoto white having high FC and twice FS in relation to the other varieties can be considered as having better foaming properties than the other varieties; and this suggests why it is often preferred locally in the preparation of 'akara' bean balls. The FC of un-infested cowpeas ranged from $7.5 \mathrm{ml}$ in Iron to $17.0 \mathrm{ml}$ and $16.0 \mathrm{ml}$ in Ife brown and Sokoto, respectively (Table 2).

Table 1: Generation of samples of infested and un-infested cowpeas

\begin{tabular}{|c|c|c|c|c|c|c|c|c|}
\hline & \multicolumn{3}{|c|}{ Infestation level (\%) } & & \multirow[b]{2}{*}{50} & & & \\
\hline & $\mathbf{0}$ & & 25 & & & \multicolumn{3}{|c|}{75} \\
\hline Cowpea varieties & Un-infested & infested & Un-infested & infested & Un-infested & Infested & Un-infested & Infested \\
\hline Ife-brown & 1000 & 0 & 750 & 250 & 500 & 500 & 250 & 750 \\
\hline Iron & 1000 & 0 & 750 & 250 & 500 & 500 & 250 & 750 \\
\hline Isiocha & 1000 & 0 & 750 & 250 & 500 & 500 & 250 & 750 \\
\hline Patasco & 1000 & 0 & 750 & 250 & 500 & 500 & 250 & 750 \\
\hline Sokoto & 1000 & 0 & 750 & 250 & 500 & 500 & 250 & 750 \\
\hline
\end{tabular}


Table 2: Effect of insect infestation on the protein content, total dietary fiber and swelling index of five cowpea varieties

\begin{tabular}{|c|c|c|c|c|c|c|c|}
\hline 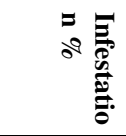 & & 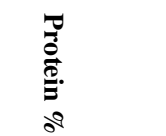 & $\begin{array}{l}\text { 컴 } \\
\text { d9 }\end{array}$ & 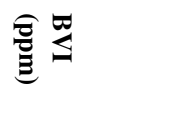 & $\stackrel{\mathscr{\varrho}}{\hat{E}}$ & 气ُ̂ & 氞 \\
\hline \multirow{6}{*}{0} & Ife-brown & 22.75 & 41 & 51.25 & 1.61 & 17.0 & 1.0 \\
\hline & Iron & 22.75 & 49 & 37.50 & 1.32 & 7.50 & 1.0 \\
\hline & Isiocha & 15.31 & 49 & 47.50 & 1.49 & 13.0 & 1.0 \\
\hline & Patasco & 21.56 & 34 & 50.00 & 1.29 & 11.0 & 1.0 \\
\hline & Sokoto & 17.50 & 40 & 37.50 & 1.39 & 16.0 & 2.0 \\
\hline & Mean & $19.97 \pm 3.38^{\mathrm{a}}$ & $42.60 \pm 6.43^{\mathrm{a}}$ & $44.75 \pm 6.75^{\mathrm{c}}$ & $1.42 \pm 0.13^{\mathrm{a}}$ & $12.90 \pm 3.85^{\mathrm{a}}$ & $1.20 \pm 0.45^{\mathrm{a}}$ \\
\hline \multirow{8}{*}{25} & Ife-brown & 17.88 & 32 & 52.50 & 1.55 & 17.0 & 1.0 \\
\hline & Iron & 12.25 & 47 & 57.50 & 1.31 & 8.0 & 0.5 \\
\hline & Isiocha & 13.58 & 42 & 62.50 & 1.43 & 8.0 & 0.7 \\
\hline & Patasco & 19.69 & 31 & 41.25 & 1.23 & 10.0 & 0.5 \\
\hline & Sokoto & 15.25 & 36 & 55.00 & 1.39 & 13.0 & 2.0 \\
\hline & Mean & $15.73 \pm 3.05^{b}$ & $37.60 \pm 6.80^{b}$ & $53.75 \pm 7.91^{\mathrm{c}}$ & $1.38 \pm 0.12^{b}$ & $11.20 \pm 3.83^{\mathrm{ab}}$ & $0.94 \pm 0.63^{b}$ \\
\hline & Ife-brown & 19.94 & 30 & 80.00 & 1.50 & 13.0 & 1.0 \\
\hline & Iron & 11.38 & 44 & 55.00 & 1.27 & 8.5 & 0.5 \\
\hline \multirow{3}{*}{50} & Isiocha & 13.22 & 38 & 65.00 & 1.33 & 7.5 & 1.0 \\
\hline & Patasco & 20.56 & 33 & 62.50 & 1.21 & 11.0 & 0.5 \\
\hline & Sokoto & 10.78 & 33 & 70.00 & 1.25 & 11.0 & 1.5 \\
\hline \multirow{8}{*}{75} & Mean & $15.18 \pm 4.72^{b}$ & $35.60 \pm 5.50^{\mathrm{bc}}$ & $66.50 \pm 9.29^{b}$ & $1.31 \pm 0.11^{\mathrm{c}}$ & $10.20 \pm 2.20^{b}$ & $0.90 \pm 0.42^{b}$ \\
\hline & Ife-brown & 18.81 & 29 & 80.00 & 1.36 & 13.00 & 1.0 \\
\hline & Iron & 21.00 & 47 & 70.00 & 1.24 & 3.50 & 0.1 \\
\hline & Isiocha & 14.75 & 32 & 98.00 & 1.26 & 5.30 & 0.9 \\
\hline & Patasco & 17.94 & 31 & 67.50 & 1.11 & 10.00 & 0.5 \\
\hline & Sokoto & 15.89 & 29 & 87.00 & 1.17 & 6.00 & 1.3 \\
\hline & Mean & $17.68 \pm 2.46^{\mathrm{ab}}$ & $33.60 \pm 7.60^{\mathrm{c}}$ & $80.50 \pm 12.53^{\mathrm{a}}$ & $1.23 \pm 0.09^{d}$ & $7.56 \pm 3.86^{c}$ & $0.76 \pm 0.47^{b}$ \\
\hline & & 15.10 & 7.86 & 13.46 & 2.16 & 17.98 & 21.05 \\
\hline
\end{tabular}

\section{CONCLUSION}

Insect infestation adversely affected the protein content, TDF, SI, FC, FS and BVI of the cowpeas studied. A moderate infestation level of $25 \%$ adversely affected most of the properties evaluated. The severity of damage caused by the insects to the properties determined in the cowpeas was generally proportional to the infestation level, occurring most in $75 \%$ infested cowpeas. The TDF and SI of Iron was least affected by insect infestation while its protein content and foaming stability was most affected. On the other hand, patasco was generally least affected by insect infestation in protein content, level of starch damage and foaming capacity while Ife brown was the least affected in foaming stability. However, un-infested Sokoto white had better foaming properties with a high foaming capacity and foam stability twice that of the other varieties. Since with a high foaming capacity and foam stability twice that of the other varieties. Since insect infestation causes damage to both the nutritional and functional properties of cowpea, urgent measures to safeguard cowpea from infestation to help reduce food insecurity and malnutrition, especially in the developing world is needed. Efforts at improving simple technologies that can be employed at household level, especially in the use of natural insecticides (e.g. spices) to safeguard cowpea should be intensified. In addition, dissemination of information among rural women on such technologies is highly recommended.

\section{REFERENCES}

Abudulai, M., Seini, S.S., Haruna, M., Mohammed, A.M. and Asante, S.K. (2016). Farmer participatory pest management evaluations and variety selection in diagnostic farmer field Fora in cowpea in Ghana. African Journal of Agricultural Research, 11: (19), 1765-1771.

African Agricultural Technology Foundation (AATF) (2012). Cowpea for food and poverty alleviation: Potentials and constraints. Available from http://www.aatf.Africa.org/files/files/publications/ Cowpea\%20brief.pdf. Accessed - August 8, 2017.

Ahmad, I.M. and Kiresur, V.R. (2016). Pulses production in India and Nigeria: Panacea to Food Security. esearch Journal of Agriculture and Forestry Sciences, 4: (6), 11-19.

Ajayi, O.E., Balusu, R., Morawo, T.O., Zebelo, S. and Fadamiro, H. (2015). Semiochemical modulation of host preference of Callosobruchus maculates on legume seeds. Journal of Stored Products Research, 63: 31-37.

Ajetomobi, J. and Abiodun, A. (2010). Climate change impacts on cowpea productivity in Nigeria. African Journal of Food, Agriculture, Nutrition and Development, 10 : (3), 2258-2271.

Akubor, P.I. (2004). Protein contents, physical and sensory properties of Nigerian snack foods (cake, chin-chin and puff-puff) prepared from cowpea wheat flour blends. International Journal of Food Science and Technology, 39: (4), 419-424.

Alale, T.Y., Opoku, N. and Adarkwarh, C. (2017). The efficacy of aqueous false yam (Icacina oliviformis) tuber extract against cowpea aphids 
(Aphis craccivora Koch). Journal of Young Investigators, 32: (4), 22-24.

Anderson, J.W., Baird, P., Davis, R.H., Ferreri, S., Knudtson, M., Koraym, A., Waters, V. and Williams, C.L. (2009). Health benefits of dietary fiber. Nutrition reviews, 67: (4), 188-205.

AOAC (2010). Official Methods of Analysis (18 $\left.8^{\text {th }} \mathrm{ed}.\right)$, Association of Official Analytical Chemists (AOAC), Washington D. C., U. S. A.

Carlos, G. (2004). Cowpea: Post-harvest Operations. In: AGST/FAO: D. Mejía (ed.), Food and Agriculture Organization of the United Nations (FAO) Information Network on Post-harvest Operations (INPhO) Compendium, FAO Rome, Italy. Available from http://www.fao.org/fileadmin/user_upload/inpho/d ocs/Post_Harvest_Compendium_Cowpeas.pdf ccessed September 1, 2012.

Consultative Group for International Agricultural Research (CGIAR) (2017). Cowpea. Available from http://www.cgiar.org/our-strategy/cropfactsheets/cowpeal. Accessed August 8: 2017.

Enwere, N.J. (1985). Effect of tempering and drying on selected functional properties and performance of cowpea flour during akara and moin-moin preparation. M. Sc. Dissertation Dept of Food Sci. \& Tech., University of Nigeria, Nsukka.

Ezema, G.O. (1989). Effects of some processing methods on African yam bean (Sphenostylis sternocarpa) seeds and flours- quoted by Oguike, R. I., B. Tech. Thesis, 1998, Food Sci. \& Tech. Federal University of Technology, Owerri, Imo State.

Food and Agriculture Organization of the United Nations Statistics Division [FAOSTAT] (2016). Available http://faostat3.fao.org/download/Q/QC/E Accessed August 10: 2017.

Gayan, R.S.R., Priyani, P. and Krishanthi, A. (2006). Physicochemical changes of stored cowpea, Vigna unguiculata, treated with selected essential oils to control cowpea bruchid, Callosobruchus maculatus (F.). J. Food Agric. Environ., 4: (3\&4), 41-44.

Ihekoronye, A.I. and Ngoddy, P.O. (1985). Integrated Food Science for the Tropics. Macmillian Education, London.

Jood, S., Kapoor, A.C. and Singh R. (1993). Biological evaluation of protein quality of sorghum as affected by insect infestation. Plants Foods Hum. Nutr., 43: (2), 105-114.

Kamai, N., Gworgwor, N.A. and Kamara, A.Y. (2014). Determination of physiological yield components among cowpea varieties in Northern Nigeria. International Journal of Advanced Biological Research, 4: (2), 122-129.

Kamara, A.Y., Tofa, A.I., Kyei-Boahen, S., Solomon, R., Ajeigbe, H.A. and Kamai, N. (2016). Effects of plant density on the performance of cowpea in Nigerian Savannas. Experimental Agriculture, 113.

Kattula, S.Y., Pandya, H.V., Kumar, S.S. and Kumar. S.G. (2017). Efficacy of different combination of insecticides against cowpea pod borer in cowpea [Vigna ungiculata (L.) Walp]. International Journal of Current Microbiology and Applied Sciences, 6: (6), 2030-2037.
Kawabata, A., Sawayama S., Nagashima, N., DelRosario, R.R. and Nakamura, M. (1984). Some physico-chemical properties of starches from cassava, arrow-root and sago, J. Jpn. Soc. Starch Sci., 39: (4), 224-232.

Kinsella, J.E. (1979). Functional properties of soy protein. J. Amer. Oil Chem. Soc., 56: 242-258

Kungu, J.K., Muroki, N. and Omwega, A. (2003). Effect of storage on the quality and safety of grains in Tharaka District, Kenya. African J. Food, Agric. Nutr. Dev., 3: (2), 1-6.

Kyei-Boahen, S., Savala, C.E.N., Chikoye, D. and Abaidoo, R. (2017). Growth and yield responses of cowpea to inoculation and phosphorus fertilization in different environments. Frontiers in Plant Sci. 8: 1-13.

Lawhen, J.I., Cater, C.M. and Mattil, K.F. (1972). Sensory and analytical evaluation of cake and doughnut fortified with protein from oil seed flour. Food Pdt. Dev., 9: (4), 110-118.

Lon D.L. (2005). Feeding and Care of the Horse $\left(2^{\text {nd }}\right.$ ed.), Blackwell Publishing, Iowa, USA, p. 17.

Lulai, E.C. (1983). Objective methods for testing potato flake quality as influenced by free starch and surfactants. American Journal of Potato Research, 60: (2), 85-98.

Mallillin, A.C., Trinidad, T.P., Raterta, R., Dagbay, K. and Loyola, A.S. (2008). Dietary fibre and fermentability characteristics of root crops and legumes. Br. J. Nutr., 100: (3), 485-8.

Margam, V.M., Coates, B.S., Ba, M.N., Sun, W., Binso-Dabire, C.L., Baoua, I., Ishiyaku, M.F., Shukle, J.T., Hellmich, R.L., Covas, F.G., Ramasamy, S., Armstrong, J., Pittendrigh, B.R. and Murdock, L.L. (2011). Geographic distribution of phylogenetically-distinct legume pod borer, Maruca vitrata (Lepidoptera: Pyraloidea: Crambidae). Mol. Biol. Rep., 38: 893903.

Mbofung, C.M.F., Aboubakar, Y.N., Njintang, A., Abdou, B. and Balaam, F. (2006). Physicochemical and functional properties of six varieties of taro (Colocasia esculenta L. Schott) flour. J. Food Tech., 4: (2): 135-142

Muchero. W., Ehlers, J.D. and Roberts, P.A. (2010). QTL analysis for resistance to foliar damage caused by Thrips tabaci and Frankliniella schultzei (Thysanoptera: Thripidae) feeding in cowpea [Vigna unguiculata (L.) Walp.]. Molecular Breeding, 25: (1), 47-56

National Research Council (2006). Cowpea. In: Lost Crops of Africa. Volume II: Vegetables. The National Academies Press, Washington, D. C, pp. 104-117.

Ngakou, A., Tamo, M., Parh, I.A., Nwaga, D., Ntonifor, N.N., Korie, S. and Nebane, C.L.N. (2010). Management of cowpea flower thrips, Megalurothrips sjostedti (Thysanoptera, Thripidae) in Cameroon. Crop Protection, 27: (35), 481-488.

Oboh, H.A. and Agu, K. (2010). The Effects of various traditional processing methods on the glycemic index and glycemic load of cowpeas (Vigna unguiculata). Journal of Food Biochemistry, 34: (6), 1332-1343.

Odejayi, A.O., Banjo, A.D. and Lawal, O.A. (2014). Biochemical Analysis of Bean weevil Infested 
Comparative Effects of Three Levels of Insect Infestation on Selected Cowpea Varieties

Cowpea Flour. The Journal of Zoology Studies, 1: (1), 19-21.

Odejayi, A. and Aina, S.A. (2016). Organoleptic test of bean weevil infested cowpea products (moinmoin and akara). The Journal of Zoology Studies, 3: (1): 35-38.

Ojimelukwe, P.C., Onweluzo, J.C. and Okechukwu, E. (1999). Effects of infestation on the nutrient content and physicochemical properties of two cowpeas (Vigna unguiculata). Plant Foods for Human Nutrition, 53: 321-332.

Okaka, J.C. and Potter N.N. (1979). Physiochemical and functional properties of cowpea powders processed to reduce beans flavor. J. Food Sci., 44: $1235-1240$.

Oladunmoye, O.O., Akinoso, R. and Olapade, A.A. (2010). Evaluation of some physical-chemical properties of wheat, cassava, maize and cowpea flours for bread making. Journal of Food Quality, 33: 693-708.

Oyeniyi, E.A., Gbaye, O.A. and Holloway, G.J. (2015). The influence of geographic origin and food type on the susceptibility of Callosobruchus maculates (Fabricius) to Piper guineense (Schum and Thonn). Journal of Stored Products Research, 63: $15-21$.

Oyewale, R.O. and Bamaiyi, L.J. (2013). Management of Cowpea Insect Pests. Scholars Academic Journal of Biosciences, 1: (5), 217226.

Sallam, M.N. (2008). Insect damage: Damage on Postharvest. Available at http://www.fao.org/3/aav013e.pdf. Accessed August 28, 2017.

Sangoyomi, T.E. and Olufunmilola, A. (2016). Field evaluation of cowpea varieties for adaptation to the forest/savanna transition agroecology of Osun state, Nigeria. African Journal of Agricultural Research, 11: (49), 4959-4963.
Sanon, A., Ba, N.M., Binso-Dabire, C.L. and Pittendrigh, B.R. (2010). Effectiveness of spinosad (naturalytes) in controlling the cowpea storage pest, Callosobruchus maculatus (Coleoptera: Bruchidae). Journal of Economic Entomology, 103 :(1), 203-210.

Singh, D.V. and Mukhi, S.K. (2017). Phasic pattern of dry matter production and accumulation in different parts of cowpea cultivars (Vigna unguiculata L. Walp.) during growth and development stages under varied seasons. International Journal of Current Microbiology and Applied Sciences 6: (4), 347-355.

Ukpabi, U.J. and Ndimele, C. (1990). Evaluation of the quality of garri produced in Imo State. Nign. Food J., 8: 105-110

Uzogara, S.G. and Ofuya, Z.M. (1992). Processing and utilization of cowpeas in developing countries: a review. J. Food Proc. Pres., 16: (2), 105-147.

Vilakati, N., MacIntyre, U., Oelofse, A. and Taylor, J.R.N. (2015). Influence of micronization (infrared treatment) on the protein and functional quality of a ready-to-eat sorghum-cowpea African porridge for young child-feeding. LWT - Food Science and Technology, 63: (2), 1191-1198. 